\title{
IMPACT OF DRUG ABUSE ON YOUTH CRIMINALITY: AN EMPIRICAL STUDY
}

\section{RUKHSANA SIDDIQUA ${ }^{1}$, MOHAMMAD ZIHAD HOSSAIN ${ }^{2} \&$ HABIBALILUNNAHAR $^{3}$}

${ }^{1}$ Doctoral Research Fellow, Jindal Institute of Behavioral Sciences, O.P.Jindal Global University, Haryana, India. Assistant Professor, Department. of CPS, MBSTU, Bangladesh

${ }^{2}$ MS and B.Sc. from Department of Criminology and Police Science, Mawlana Bhashani Science and Technology University, Tangail, Bangladesh

${ }^{3}$ MS Student, Department of Criminology and Police Science, Mawlana Bhashani Science and Technology University, Tangail, Bangladesh

\begin{abstract}
The drug trade has become a lucrative business; as a result, youth criminality rises as a greater social problem at the present time. The concerning fact is that drug abuse destroys youth productivity and influences youth criminality. This paper intended to find out the interrelationship between drug abuse and youth criminality through face to face interviews withthe addicted youths. Drug availability, negative peer association, curiosity, pleasure, lack of social support, unemployment problems, family dysfunction, and frustration are influencing the youth to take drugs as well as to commit crimes. Particularly, drug availability, curiosity, and negative peer association are the most common risk factors of drug abuse and youth criminality. Besides, the drugs are now available even in the ruralareas and the students are the main victims of these illegal drug businesses. Most of the addicted youth are involved in the drug trade and that leads them toward committing criminal activities. If we want to remove drug abuse and youth criminality, the root causes should be identified first and we should provideour young generation a social environment free from drug availability, good peer association, sufficient social and family support to reduce all types of frustration in the socialization process. Hence, the family members, society, and the government should take the necessary steps to stop these problems, for our own national peace and prosperity.
\end{abstract}

KEYWORDS: Drug Abuse, Youth Criminality, Peer group, Curiosity, Recidivism

Received: Jun 05, 2020; Accepted: Jul 25, 2020; Published: Aug 20, 2020; Paper Id.: IJEEFUSAUG20202

\section{INTRODUCTION}

The availability of illegal drugs is a clear threat to our country as the youth are the main victims of these illegal drugs. There are millions of drug-addicted people in Bangladesh and most of them are young people. According to BSS (2013), the trend of drug consumption is higher in youth and teenagers, their age is spanning between 15 to 30 years. In a research, Khan and Rahman (2012) demonstrated that most of the drug abusers in Bangladesh are aged between 20 to 25 years and 67 percent had committed acrime after taking drugs. The BSS (2013) also reported that around ten thousand cases are filed and nine hundred people are arrested every year in connection with drugrelated violence and crimes. In 2013, Khatun and Anwar found that about $61.5 \%$ of drug abusers collect money for buying drugs by illegal means. These findings showed that there is both direct and indirect connection between drug abuse and youth criminality and the youth generation of our country is most vulnerable to the curse of illegal drugs. The illegal use of drugs has evil consequences as drugs rapidly decrease the educational, social, cultural, moral, and family values. As a result, the people taking drugs frequentlylose their productivity, professional and educational capabilities, and self-dignity. The continuous habit of taking drugs also damages the psychological, 
physical, mental, moral, ethical condition. Atlanta Police Department pointed out the addicts aredesperate for cash to feed their habits and can commit murder. Khan (2013) explored that, around six million drug users in Bangladesh spend over Tk. 70m every day for illegal narcotics. Oishi is the prominent example that we had witnessed, the murder of parents by their own drug-addicted daughter. Though we are aware of single incident, there are so many parents in our country who are suffering the same problem. The drug abusers are more likely to commit a crime again and again as Anglin and Maugh (1992) found that, those who are involved in regular use of hard drugs are typically at high risk of recidivism. Drug abusers are more likely to commit crime than normal peoples as Inciardi noted that 356 addicts in Miami committed 118,134 offenses over a one-year period. In a study, Beaukimer and Reuters (2000) found that nearly one-quarter (22 percent) of the federal prison inmates and one-third (33 percent) of state prison inmates were convicted for offences like robbery, burglary, or motor vehicle theft were recorded being under the influence of drugs. On the other hand, among the state and federal inmates, 27 percent of those serving sentences for robbery and 30-32 percent of those serving sentences for burglary confessed that they committed offenses to buy drugs. American National Surveys of inmates in Jails and Prisons found that about 40 percent of the convicted offenders incarcerated for cognizable offenses had used alcohol immediately before the crimes. Noteworthily, most of the time the drivers accused of road accidents arefound to be heavy drug abusers. American's National Statistics indicated that about 45 percent of prison inmates accused of road accidents was driving while intoxicated. Also, drug and alcohol abuse are liable for a high rate of homicide, as Brownstein (1992) reported that about 53 percent of homicides are committed by drug addicts. According to Jones (1999), a third of all thefts, burglaries, and street robberies are committed by drug-addicted offenders. Therefore, the availability of drugs is a direct threat to our national law and order situation as well as to our national development as it is affecting our youth generation.

There is ample evidence that drug use increases individual's involvements in criminal activities (Bennett, 1998 and 2000). Scholars claimed that majority of addicts commit economic-associated crimes to sustain their addictive behavior. Others suggested that drug users are involved more frequently in personal crimes like assault, family conflicts quarrels, violent crimes, and prostitution. In this regard, Goldstein (1985) said that there is a causal connection between drug use and violence. Though this context, micro factors are those that are learned in the process of interaction. Social deviation and criminality that are learned through peer pressure, family members, on the street, at school, contact with criminal justice agencies, mass media, frustration etc. However, macro factors predisposing individual to social deviation and criminality are structural. Notably, structural factors are social disorganization, low social control, social problems caused by social structure, population heterogeneity, environmental factors, inequality, unemployment, poverty, broken homes etc. (Goldstein,1985). Apparently, the connection between drug use and crime involved with illicit drug sales and abuse is a necessary prerequisite to illicit drug trade. Hence, the drug market is one mechanism by which substance abuse causes crime that follows logically.

Existing theoretical and empirical studies reveal that youth criminality is involved in drug abuse. Differential Association Theory (1947) developed by Sutherland proposed that when a person interactswith another person,theyare influenced by each other in terms of behavior. Differential association refers to the process whereby one is exposed to normative definitions favorable or unfavorable to illegal or law-abiding behaviors (Akers, 2000). The first proposition of the differential association theory is that criminal behavior is learned. In this sense, drug addiction is learned and a process of symbolic interaction with others, mainly in primary or inmate groups. The principle of differential association is a person taking drugs and committing criminal acts because he or she has learned "definition" (rationalizations and attitudes) favorable to taking drugs in 'excess' of the definitions unfavorable to taking drugs. Drug addiction is learned and practiced 
in interaction with other people in the process of communication. The learning of drug addiction includes (a) techniques of taking drugs, which is sometimes very complicated, sometimes very simple, and (b) the specific direction of motives, drives, rationalizations, and attitudes. Therefore, Sutherland's theory is an instigating agent of learning drug-related offenses (Ahuja, 1996). In contrast, Hirschi's Social Bonding Theory explains that attachment, commitment, involvement, and beliefs are important for the social bond. Those stronger social bonding with parents, adults, school teachers, and peers are more likely desist from crime (Berg and Huebner, 2011; Visher and Travis, 2011; Sampson and Laub, 1993) and individual's behavior will be controlled. However, the weaker is the more likely it is that the individual will not control his or her normal behavior and frustration for incapability to bonding with others. Hence, uncontrolled behavior and frustration accelerate him to take drugs and commit drug-related offenses for feeding drug substances.

Over and above, this analysis offers a broad and clearer picture of drug abuse and youth criminality explaining with various factors related to youth criminality influence by drug addiction. Furthermore, this analysis has been conducted by identifying some variables which are explained cause and effect by using quantitative statistical tools. Finally, some primary key points were identified, including- socio-demographic characteristics of the respondents, Duration of drug abuse, Causes of drug abuse, family dysfunction and abuse, Sources of drug, Frustration and drug abuse, Nature of crimes for drug addiction and drug dependency and recidivism of youth.

\section{OBJECTIVES OF THE STUDY}

The main objective of the study is to find out the correlation between drug abuse and youth criminality. The specific objectives of the study are given below.

- To identify the nature and extent of criminal activities due to drug abuse.

- $\quad$ To find out the negative impacts of drug abuse over youth generation.

- To explain the influencing factors of drug abuse and youth criminality.

\section{RESEARCH METHODOLOGY}

This study focuses ondrug-addicted people who have committed crimes due to drug addiction. Following the nature of this research, we selected two-drug treatment centers "Decide Drug Treatment Center in Tangail" and "Path Drug Rehabilitation Center in Manikganj” as well as selected a vital area of drug-addicted people besides MawlanaBhashani Science and Technology University (MBSTU).In this research, non-probability sampling we had chosenquota sampling method to selected respondents. For this reason, we have divided study area into different strata or quota like two treatment centers and Santosh area. In addition, we used quota sampling for collecting data and the total population of the study area is not properly defined. On the other hand, it was impossible to select respondents randomly from the Drug Treatment Center. For this reason, we had chosen quota sampling to select a site and snowball sampling methods to find out the respondents under non-probability sampling. This research is analytical and quantitative in nature; data had been collected by face to face interview system following a structured questionnaire from 50 respondents. Moreover, to process and analyze the data, different types of statistical tools like univariate analysis had been used in this research like charts, graphs, cross-tabulations, and chi-square tests, etc. 


\section{FINDINGS AND DISCUSSIONS}

\section{Findings of the Study}

\section{Socio-Demographic Characteristics of the Respondents}

Table-1 discusses about the socio-demographic characteristics of the respondents. This paper presents that most of the drug abusers (54 percent) are youth and their age group is 20-25 years old. Several studies also suggest that, majority of drug abusers in Bangladesh are youth and their age is spanning between 15 and 30 years (BSS, 2013), 20-25 years (Khan and Rahman, 2012). In terms of educational qualification, 56 percent are educated over SSC level but someof them ended their study before passing HSC. In a study it was found that about 56 percent of the drug abusers are either student or unemployed (ICDDRB, 2013). Most of the drug abusers of the study are found students (68 percent) reading in College and Universities. On the other hand, most of respondents are found unmarried (56 percent) similar to a research finding that about 56 percent drug abusers are found unmarried (Khatun and Anwar, 2013). This paper also reveals that most of the drug abusers belong to single family (78 percent) and their monthly income is below 10 thousand taka (74 percent). Therefore, it can be concluded that the majority of the drug abusers in Bangladesh are youth in age and come from lower or middle class single families. The unmarried youth are also found more likely to be involved in drug abuse and criminal activities.

Table1: Socio-Demographic Characteristics of the Respondents

\begin{tabular}{|c|c|c|}
\hline Variables & Frequency & Percent \\
\hline \multicolumn{3}{|c|}{ Age Group } \\
\hline 20 and above & 9 & 18 \\
\hline $20-25$ & 27 & 54 \\
\hline $25-30$ & 6 & 12 \\
\hline $30-35$ & 3 & 6 \\
\hline Over 35 & 5 & 10 \\
\hline Total & 50 & 100 \\
\hline \multicolumn{3}{|c|}{ Educational Qualification } \\
\hline Illiterate & 1 & 2 \\
\hline Primary & 7 & 14 \\
\hline Secondary & 14 & 28 \\
\hline Higher Secondary & 8 & 16 \\
\hline Over HSC & 20 & 40 \\
\hline Total & 50 & 100 \\
\hline \multicolumn{3}{|c|}{ Family Type } \\
\hline Joint & 10 & 20 \\
\hline Single & 39 & 78 \\
\hline Broken & 1 & 2 \\
\hline Total & 50 & 100 \\
\hline \multicolumn{3}{|c|}{ Monthly Income } \\
\hline Below 10000 & 37 & 74 \\
\hline $10000-20000$ & 5 & 10 \\
\hline $20000-30000$ & 3 & 6 \\
\hline $30000-40000$ & 1 & 2 \\
\hline Over 40000 & 4 & 8 \\
\hline Total & 50 & 100 \\
\hline \multicolumn{3}{|c|}{ Occupation } \\
\hline Labor & 9 & 18 \\
\hline Student & 34 & 68 \\
\hline Businessman & 5 & 10 \\
\hline No Job & 2 & 4 \\
\hline Total & 50 & 100 \\
\hline
\end{tabular}




\section{Factors of Drug Abuse}

Table-2 discusses about the overall factors that influence an individual to become drug addicted. Most of the respondents take drugs only to meet up their pleasure (68 percent)and another 22percenttake drugs to reduce pain and frustration. On the other hand, most of the respondents started taking drugs first time only for curiosity and pleasure (70 percent) while about 18 percent started due to frustration and inferiority, 4 percent of them due tomental disorders and 8 percent of them due tofailure in love.From this study, 58 percent respondent has informed that peer group pressure and friends was their vital cause of taking drugs. Besides 20 percent informed frustration, 12 percent family matters and 10 percent identified drug dependency. It shows that bad friends circle plays a vital role ininfluence of drug addiction. Hence, curiosity and frustration are the first stage of experiencing drugs with a bad peer group and taking drugs continuously lead to drug dependency.

Table 2: Factors of Drug Abuse

\begin{tabular}{|c|c|c|}
\hline Variables & Frequency & Percent \\
\hline \multicolumn{3}{|c|}{ Causes of Drug Abuse } \\
\hline Pleasure & 34 & 68 \\
\hline Reducing pain/Frustration & 11 & 22 \\
\hline Stimulate & 4 & 8 \\
\hline Others & 1 & 2 \\
\hline Total & 50 & 100 \\
\hline \multicolumn{3}{|c|}{ Cause of Taking Drugs First Time } \\
\hline Curiosity and Pleasure & 35 & 70 \\
\hline Frustration and Inferiority & 9 & 18 \\
\hline Mental disorder & 2 & 4 \\
\hline Failure in Love & 4 & 8 \\
\hline Total & 50 & 100 \\
\hline \multicolumn{3}{|c|}{ Vital Cause of Taking Drugs } \\
\hline Family Matters & 6 & 12 \\
\hline Peer Group and Friends & 29 & 58 \\
\hline Drug dependency & 5 & 10 \\
\hline Frustration & 10 & 20 \\
\hline Total & 50 & 100 \\
\hline \multicolumn{3}{|c|}{ Nature of Frustration } \\
\hline No frustration & 16 & 32 \\
\hline Love Related & 11 & 22 \\
\hline Economic Problem & 5 & 10 \\
\hline Unemployment & 4 & 8 \\
\hline Family Problems & 14 & 28 \\
\hline Total & 50 & 100 \\
\hline \multicolumn{3}{|c|}{ Influence of Drug Availability } \\
\hline Highly & 41 & 82 \\
\hline Lightly & 4 & 8 \\
\hline No effect & 5 & 10 \\
\hline Total & 50 & 100 \\
\hline \multicolumn{3}{|c|}{ Influenced by } \\
\hline Friends and Peer Group & 40 & 80 \\
\hline Relatives & 5 & 10 \\
\hline Others & 5 & 10 \\
\hline Total & 50 & 100 \\
\hline
\end{tabular}

These findings also give clear evident that drug availability increases drug addiction as 80 percent of respondents supported that drug availability has high influence on large number of drug addicts because they can manage drugs easily. 
In terms of influence, majority of the respondents ( 80 percent) were influenced by their friends and peer groups. Therefore, peer group and friend circle play the prime role of attracting a person to be involved in drug addiction. It means that peer group relationship is more vital cause of drug addiction than family relationship. In this matter, the family members should keep monitoringtheir children's peer groups and friends.

\section{Family Relationship and Drug Addiction}

According to the table-3, it is found that the drug abusers were mostly properly pleased or pleased (64 percent) with their families while 30 percent weren't also pleased with their families. On the other hand, after taking drugs most of drug abusers lost good relationship with their families. Before taking drugs about 70 percent respondents have good or very good relationship with family members but after involving in drug abuse the percentage decreases to 40 percent.

Table 3: Family Relationship and Drug Addiction

\begin{tabular}{|l|c|c|}
\hline \multicolumn{1}{|c|}{ Variables } & Frequency & Percent \\
\hline \multicolumn{2}{|c|}{ Fulfillment of Basic Demands by the Family } \\
\hline Properly & 17 & 34 \\
\hline Pleased & 15 & 30 \\
\hline Not pleased & 15 & 30 \\
\hline Can't & 1 & 2 \\
\hline Partially & 2 & 4 \\
\hline Total & 50 & 100 \\
\hline \multicolumn{2}{|c|}{ Level of Relationship before Taking Drugs } \\
\hline Very Good & 10 & 20 \\
\hline Good & 25 & 50 \\
\hline Medium & 11 & 22 \\
\hline Bad & 4 & 8 \\
\hline Total & 50 & 100 \\
\hline \multicolumn{2}{|c|}{ Level of Relationship after Taking Drugs } \\
\hline Very Good & 5 & 10 \\
\hline Good & 15 & 30 \\
\hline Medium & 17 & 34 \\
\hline Bad & 13 & 26 \\
\hline Total & 50 & 100 \\
\hline
\end{tabular}

Therefore, it can be said that family matters have no big influence on becoming drug abusers but the families should take more time to stand beside the drug victim to help them to recover properly because this finding show that drug addiction gradually decreases family attachment.

\section{Types and Availability of Drug}

In this study, it has found that most of the respondents take Marijuana (38 percent), then 24 percent of them take alcohol and Marijuana at a time. There are also 16 percent people who take Marijuana, Yabba, Alcohol, Heroin as well as some non-conventional type of drugs like sleeping pills, Gum etc.In 2012 Tauhid Hossain Khan and Dr. Md. Ziaur Rahman, found that, about 62 percent respondents of Bangladesh are addicted by Marijuana, Yabba, alcohol, Viagra etc. 
Table 4: Types and Availability of Drug

\begin{tabular}{|c|c|c|}
\hline Variables & Frequency & Percent \\
\hline \multicolumn{3}{|c|}{ Types of Drugs } \\
\hline Heroin & 1 & 2 \\
\hline Alcohol & 2 & 4 \\
\hline Marijuana & 19 & 38 \\
\hline Yaba & 4 & 8 \\
\hline Alcohol \&Marijuana & 12 & 24 \\
\hline Heroin, Alcohol\&Marijuana & 4 & 8 \\
\hline All & 8 & 16 \\
\hline Total & 50 & 100 \\
\hline \multicolumn{3}{|c|}{ Sources of Drug Collection } \\
\hline Relatives & 4 & 8.0 \\
\hline Dealers & 29 & 58.0 \\
\hline Slum Area & 6 & 12.0 \\
\hline Friends & 11 & 22.0 \\
\hline Total & 50 & 100.0 \\
\hline
\end{tabular}

Most of drug abusers collect drugs from dealers (58 percent). They also collect drugs from friends (22 percent), slum areas (12 percent) and also from relatives ( 8 percent).It reveals that drug dealers are spreading all over the country even in village and rural area. The business of illegal drugs are being committed by the drug peddler or local dealers very easily as the respondents have informed that they didn't feel any sort of big problem to collect drugs.

\section{Drug Abuse and Criminal Activities}

According to table-5, most of the respondent's (68 percent) daily expenditure is below 200 taka in a day, 12 percent needs 200-500 taka and over 2000 taka also. And only 8 percent needs 500-1000 taka in a day. In terms of collecting this money for buying drugs, most of the respondent managed money for buying drugs by theft and fraud (34 percent), 24 percent by theft, fraud and extortion. Besides, about 18 percent are involvedwith all types of offences including hijacking. On the other hand, drug addiction influences an individual to commit crimes. According to the table-5, most of the respondents are involving in theft (64 percent) for drug addiction, 6 percent in fraud, 4 percent in sexual offence and assault and 20 percent involving in all offences with extortion. In terms of types of crime, the study reveals that 87.54 percent respondents are involved in income generating or property crimes like theft, fraud, extortion and also assault in taking money from others. This study also reveals that, among 50 respondents 68 percent are not involving in drug trade or supply but 32 percent are involved indirectly. This means some youth are highly addicted and involving in drug trade or supply as medium of earning. Several studies also presented that the drug abusers needs a big amount of money for buying drugs (Khan, 2013) and they maintain cost by various illegal means like robbery and assaults (Beaukimer and Reuters 2000: 8). 
Table 5: Drug Abuse and Criminal Activities

\begin{tabular}{|c|c|c|}
\hline Variables & Frequency & Percent \\
\hline \multicolumn{3}{|c|}{ Daily Expenditure for Buying Drugs } \\
\hline Below 200 take & 34 & 68 \\
\hline $200-500$ & 6 & 12 \\
\hline $500-1000$ & 4 & 8 \\
\hline over 2000 taka & 6 & 12 \\
\hline Total & 50 & 100 \\
\hline \multicolumn{3}{|c|}{ Sources of Money for Drugs } \\
\hline Theft & 12 & 24 \\
\hline Theft, Fraud and Extortion & 12 & 24 \\
\hline Theft and Fraud & 17 & 34 \\
\hline All including Hijacking & 9 & 18 \\
\hline Total & 50 & 100 \\
\hline \multicolumn{3}{|c|}{ Types of Offences due to Drug Addiction } \\
\hline Theft & 32 & 64 \\
\hline Fraud & 3 & 6 \\
\hline Extortion & 1 & 2 \\
\hline Sexual Offence & 2 & 4 \\
\hline Assault & 2 & 4 \\
\hline All & 10 & 20 \\
\hline Total & 50 & 100 \\
\hline \multicolumn{3}{|c|}{ Offences against Family } \\
\hline Assault & 1 & 2 \\
\hline Theft & 23 & 46 \\
\hline Fraud & 1 & 2 \\
\hline Theft and Fraud & 10 & 20 \\
\hline Assault and Theft & 12 & 24 \\
\hline All & 3 & 6 \\
\hline Total & 50 & 100 \\
\hline \multicolumn{3}{|c|}{ Involvement in Drug Trade } \\
\hline Yes & 16 & 32 \\
\hline No & 34 & 68 \\
\hline Total & 50 & 100 \\
\hline
\end{tabular}

In 2012, Tauhid Hossain Khan and Dr. Md. Ziaur Rahman also found that67 percent respondents reported that they had committed crime as aresult of drug use. In terms of types of crimes, the study reveals that 87.54 percent respondents are involved in income generating or property crimes like theft, fraud, extortion and also assault in taking money from others. It is also said that the drug-crime relationship is interactive (Inciardi et al., 1993, Baron, 1999, Karofi, 2012). Therefore, it can be said that, continuous taking drugs encourages more use of drugs and more use of drugs in turn encourages more crimes. There is a clear evidence that as a person's drug abuse increases his involvements in criminal activities (Bennett 1998, 2000). Some argue that most addicts commit property related crimes to sustain their addictive life style. Others opinion is that drug users are more frequently involved in personal crimes like assault, family quarrels, violent crimes and prostitution. ICDDRB (2013) also claimed that more than 100,000 people are directly involved in illegal drug trade and supplying the drugs. Hence, there is s a clear nexus between drug abuse and youth criminality.

\section{Drug Abuse and Recidivism}

It is matter of sorrow that about 96 percent respondents are involved in recidivism and only 4 percent are not involving in recidivism (Table-6). It shows that drug abusers are mostly involved in same offences again and again. Most of the respondents have informed that they were involved in recidivism due to drug dependency (34 percent), 26 percent pointed 
pleasure, 20 percent for family members, 12 percent for peer group pressure and 8 percent also informed unemployment influences recidivism.

Table 6: Drug Abuse and Recidivism

\begin{tabular}{|c|c|c|}
\hline Variables & Frequency & Percent \\
\hline \multicolumn{3}{|c|}{ Involvement in Recidivism } \\
\hline Affirmative & 48 & 96 \\
\hline Negative & 2 & 4 \\
\hline Total & 50 & 100 \\
\hline \multicolumn{3}{|c|}{ Cause of Recidivism } \\
\hline Family Problems & 10 & 20 \\
\hline Unemployment & 4 & 8 \\
\hline Pleasure & 13 & 26 \\
\hline Drug Dependency & 17 & 34 \\
\hline Friends and Environment & 6 & 12 \\
\hline Total & 50 & 100 \\
\hline
\end{tabular}

Therefore, the most common causes of recidivism are drug dependency, pleasure and family problems. Besides, drug dependency and pleasure play more negative effect on recidivism than family problems.

\section{Cross Tabulation}

\section{Relation between Area and Sources of Collecting Drugs}

From the cross table-1, it is seen that the most of the young people of towns, villages or sub-towns collect drugs from dealers (58 percent) and youth of city areas collect from slum areas.So it is a concerning issue that the drug dealers are spreading all over the Bangladesh as most of the drug abusers can easily find illegal drugs from their local dealers or peddlers.

Table 7: Area of Residence Sources of Drug Collection

\begin{tabular}{|l|c|c|c|c|c|}
\hline \multirow{4}{*}{$\begin{array}{c}\text { Area of } \\
\text { Residence }\end{array}$} & \multicolumn{4}{|c|}{ Sources of Drug Collection } & \multirow{2}{*}{ Total } \\
\cline { 2 - 5 } & Relatives & Dealers & Slum Area & Friends & \\
\hline $\begin{array}{l}\text { City } \\
\text { Village }\end{array}$ & 0 & 0 & 2 & 0 & 2 \\
\cline { 2 - 5 } Town & 1 & 15 & 0 & 6 & 22 \\
\cline { 2 - 5 } Sub-Town & 1 & 10 & 3 & 2 & 16 \\
\cline { 2 - 5 } Total & 2 & 4 & 1 & 11 & 50 \\
\hline
\end{tabular}

\section{Relation between Marital Status and Criminal Activities}

From the cross table-2, it can be easily said that the unmarried people(54 percent) are more likely to involve in drug abusing and youth criminality than married (38 percent) people.Several studies also supported that about 56 percent drug abusers are found to be unmarried and many of them are involved in criminal activities (Khatun and Anwar, 2013).

Table 8: Marital Status * Criminal Activities

\begin{tabular}{|l|c|c|c|}
\hline \multirow{2}{*}{ Marital Status } & \multicolumn{2}{|c|}{ Involvement in Recidivism } & \multirow{2}{*}{ Total } \\
\cline { 2 - 3 } & Yes & No & \\
\hline Married & 19 & 0 & 19 \\
\hline Unmarried & 27 & 1 & 28 \\
\hline Widow & 2 & 1 & 3 \\
\hline Total & 48 & 2 & 50 \\
\hline
\end{tabular}




\section{Relation between Occupation and Youth Criminality}

From the cross table-3, it can be said that the students and laborers are more likely to beinvolveewith drug addiction and committing crimes like theft than others. The ICDDRB (2013) also found that about 56 percent of drug abusers are found to be mostly either students or unemployed people.

Table 9: Occupation Youth Criminality

\begin{tabular}{|l|c|c|c|c|c|c|c|}
\hline \multirow{2}{*}{ Occupation } & \multicolumn{9}{|c|}{ Types of Offence for Drug Addiction } & Total \\
\cline { 2 - 8 } & Theft & Fraud & Extortion & $\begin{array}{c}\text { Sexual } \\
\text { Offence }\end{array}$ & Assault & All & \\
\hline Labor & 6 & 2 & 0 & 0 & 0 & 1 & 9 \\
\hline Student & 21 & 1 & 1 & 2 & 2 & 7 & 34 \\
\hline Businessman & 4 & 0 & 0 & 0 & 0 & 1 & 5 \\
\hline Unemployed & 1 & 0 & 0 & 0 & 0 & 1 & 2 \\
\hline Total & 32 & 3 & 1 & 2 & 2 & 10 & 50 \\
\hline
\end{tabular}

So it is clear that most of the time the young students and laborers take drugs and commit various offences like theft, fraud, extortion, sexual offences and assault etc.

\section{HYPOTHESIS TEST}

\section{Hypothesis Test-1}

Research Hypothesis: Curiosity is the main cause of drug addiction than other factors.

Null Hypothesis: There is no difference between curiosity and other problems in generating drug addiction.

Independent Variables: Cause of taking drugs-Nominal level (Curiosity and Pleasure, Frustration, Family problems, others)

Dependent Variable: Involvement in Recidivism due to drug addiction- Nominal level (yes versus no).

\section{Chi-Square Test: 1}

\begin{tabular}{|l|c|c|c|}
\hline \multicolumn{1}{|c|}{ Count } & Value & df & Asymp. Sig. (2-sided) \\
\hline Pearson Chi-Square & $24.724^{\mathrm{a}}$ & 3 & .001 \\
\hline Likelihood Ratio & 7.771 & 3 & .051 \\
\hline
\end{tabular}

From the Pearson Chi-Square test we can see that when significance level is 0.001 and df is 3 the calculated value is 24.724 but the table value is 16.27 . So CV is greater than TV. So the null hypothesis is rejected.

From the statistical test we can say that there is a positive relation between curiosity and drug abuse and youth criminality. So research hypothesis is accepted. Curiosity plays a bigger role than frustration and family problems in creating drug abusers and youth criminals. Curiosity is a big risk factor in this matter.

\section{Hypothesis Test-2}

Research Hypothesis: Largeamount of daily expenditure for drug addiction promotes property crime.

Null Hypothesis: There is no direct relation between amounts of daily expenditure for youth drug addiction with property crimes.

Independent Variable: Involvement in recidivism due to Drug addiction, Nominal level-(Yes versus No).

Dependent Variable: Types of crimes, Nominal level- Property crime (Theft, extortion). 
Chi-Square Test: 2

\begin{tabular}{|l|l|l|l|}
\hline \multicolumn{1}{|c|}{ Count } & \multicolumn{1}{c|}{ Value } & DF & \multicolumn{1}{c|}{ Asymp. Sig. (2-sided) } \\
\hline Pearson Chi-Square & $28.461^{\mathrm{a}}$ & 20 & .01 \\
\hline Likelihood Ratio & 24.027 & 20 & .241 \\
\hline
\end{tabular}

From the Pearson Chi-Square test it can be seen that when significance level is 0.01 and df is 20 the calculated value is 28.461 but the table value is 37.57 . So CV is smaller than TV. So the null hypothesis is accepted.

From the statistical test we can say that there is no positive relation between amounts of daily expenditure with amount of criminal offences due to drug addiction. So research hypothesis is rejected. So there is no influence of large amount of money for drug abusing on amount of offences, though managing money for buying drugs promotes youth to take illegal means.

\section{DISCUSSIONS}

Drug abuse and youth criminality are the two major social problems in almost all the countries in the world. At present drugs are spreading to all classes of people as the students of higher education are also taking drugs due to curiosity and they are being influenced by their environment as well as their bad friends and peer groups. They are mostly involved in theft, fraud, extortion, hijacking, drug selling, assault, sexual offences etc. In our country, dugs are now available and people can easily buy them from dealers even in villages as there are so many dealers to supply drugs to rural people. Besides, slum areas and prostitution areas are also a great source of drugs. As a result, people of all classes are involved with drug addiction; especially the young generations are involved mostly as they deal with frustration, family problems, unemployment etc. Mixing with bad peer groups and friends is also an important factor and it can be said that it is the only cause of drug addiction. Most of the drug abusers started to take drugs for curiosity and pleasure as they feel frustration of unemployment. So they need awareness about the bad effects of taking drugs as well as ensure vocational education and proper job assurance. Many of them blame their surroundings, drug availability, lack of counseling, treatment for their drug taking and criminal offences. So the Government as well as the society should ensure a drug free society taking different programs, counseling, society involvement, and public awareness and the media can also play a great role to stop drug addiction and youth criminality. Existing laws to prevent drug supply, trade also need to be enforced strictly.

From this study it is found that most of the drug abusers are young, unmarried, and not rich and take drugs at a very young age. So awareness should be increased about negative effects of drug abuse. In this study, the researchers wanted to know how drug abuse and youth criminality can be prevented. The positive side is that all of them were interested in giving up drug abuse and criminal activities. They argued that strong will power, proper family support, awareness of bad effect of taking drugs, social support, educational publication about bad effect of drug taking, friends support, proper treatment, public awareness, reducing frustration, good and favorable environment, vocational education, strict punishment, punishing the dealers, destroying drug factories, moral and religious values, developing patriotism, providing proper job, reducing conflict, proper love and affection, reduce availability of drug, strict laws, proper counseling and motivations, governmental programs as well as support from the media can be helpful to remove both drug abuse and youth criminality.. 


\section{CONCLUSIONS}

Youth criminality has always been considered as a concerning issue almost in every country in the world. The youth are deemed and expected to be the steering part of citizenry, on whom the development and prosperity of a country depend. But Bangladesh is facing a great problem of youth criminality due to drug abuse. Prison statistics of Bangladesh also reveals that the youth are mostly involved in different criminal activities. It is also proved that most of the youth are committing crimes due to drug abuse. Drug availability, bad peer group, demand of curiosity and pleasure, lack of social support, unemployment problems, family problems, frustrations as well as many other adverse social environment are also influencing the youth to take drugs as well as to commit criminal activities. Among them drug availability, curiosity and influence and bad peer group's influence are the biggest risk factors of drug abuse and youth criminality. So family members, society and the government should take necessary steps to stop these problems as soon as possible; otherwise this country will never see the hope of development and peace. Besides, our young generation can be engaged in many development processes only by listening their problems, providing them good family support, good peer group, good friend circle, vocational and educational training, moral and ethical treatment, proper treatment, social support, reducing frustration, proper motivation and counseling, good familiar and social environment, alerting them about the bad effects of taking drugs, strict laws against youth criminality, proper empowerment, effective national policy and strict legal action to ensure drug-free society.

\section{REFERENCES}

1. Adler, F., Muller, Gerhard. W. \& Laufer, William.S.(2005). Criminology, $5^{\text {th }}$ edition, New York: McGraw-Hill Higher Education.

2. Ahuja, R. (1996). “Sociological Criminology”, New Delhi: New Age Internation Publishers Limited.

3. Akers L. Ronald (2000) “Criminological theories: Introduction, Evaluation and Application”, Los Angeles: Roxbury Publication Company.

4. Aljammali, Zainab Mahmood. "Effect of Drugs on Teeth and Gums-A Review. "TJPRC: International Journal of Pedodontics and Preventive Dentistry (TJPRC:IJPPD) l. 1,.1, Jun 2015, 1-8

5. Baker L. Theres "Doing Social Research (Third Edition)”, (California State University, San Marcos Community Epidemiology Work Group. Acarid, L. F., BurtonJr, V. S. and

6. Baron, S. N. (1999). Street Youth and Substance Abuse. Youth and Society, 3(1):3-24

7. Becker, H. S. (1963). Outsiders: Studies in the Sociology of Deviance. New York Free Press.

8. Bennett, T. (1998). Drugs and Crime: The Results of Research on Drug Testing and Interviewing

9. Bennett, T. (2000). Drugs and Crime: The Results of the Second Development of the New-ADAM Programs.

10. Berg, M. T., \& Huebner, B. M. (2011). "Reentry and the Ties that Bind: An Examination of Social Ties, Employment, and Recidivism.” Justice Quarterly, 28(2), 382-410.

11. Bharathi, T. Aruna. "A Study on the Self-Esteem Level among the Students of College of Home Science." International Journal of Educational Science and Research (IJESR) 7.5 (2017): 71-76.

12. BSS-A news agency of Bangladesh (2013).Drug Abuse Alarmingly Rising in Bangladesh. The Daily Star, 14

13. Bushman, B.J. (1996).Individual Differences in the Extent and Development of Aggressive Cognitive associative. 
14. Cabrera, S. S. (1999). Drug Use among Hispanic Youth: Examining Common and Unique Contributing

15. Cullen, F. T. (2000). Gender and Crime among Felony Offenders: Assessing the Generality of Social control and Differential Association Theories.

16. Dashe, J.S.; Jackson, G.L.; Olscher, D.A.; Zane, E.H.; and Wendel, G.D., Jr. Opioid detoxification in pregnancy. Obstet Gynecol 92(5):854-858, 1998.

17. Dole, V.P.; Nyswander, M.E.; and Kreek, M.J. Narcotic blockade. Arch Intern Med 118(4):304-309, 1966. Epidemiologic Trends in Drug Abuse, Vol. II, Proceedings of the Community Epidemiology Work Group, December 2003. NIH Pub. No. 045365. Bethesda, MD: NIDA, NIH, DHHS, 2004.

18. Feroz, R. A. (2013). Drug Abuse in Bangladesh. Retrieved from: http://www.newstoday.com.(on 12.02.2012).

19. Goldstein, P. (1985). The Drug/violence Nexus: A tripartite conceptual framework.

20. Inciardi, J. A., Horowitz, R. and Pottieger, A. E. (1993).Street Kids, Street drugs, Street Crimes. Belmont, CA

21. Jerah, A. B. A., ANIL KUMAR Bidwai, and MOHAMMAD SHABBIR Alam. "A review of the history, cultivation, chemistry, pharmacology and adverse health effects of Khat." Int. J. Appl. Nat. Sci. 6.3 (2017).

22. Johnson, B. D., Golub, A. and Fagan, J. (1995). Careers in Crack, Drug Use, Drug Distribution and nondrug

23. Khan. H. Tauhid (2002) and Rahman. Ziaur on their study "Drug-Crime Nexus on the Youths of Selected Urban Areas in Munshiganj District, Bangladesh

24. Khatun.Taslima (2013) and Anwar.Saeed's research on "Public Concern towards Drug Addiction with the help of Field Survey, 2013 under BANGLADESH RESEARCH PUBLICATIONS JOURNAL.

25. Leslie, J. R. (1989). Family Dysfunctions and Female Delinquency. Crime and Delinquency 35(1): 31-44.

26. Ramsay, M. and Percy, A. (1996). Drug Misuse Declared: Results of the 1994 British Crime Survey: Home

27. Sampson, R., \&Laub, J. (1993).Crime in the making. Cambridge, MA: Harvard University Press.

28. Single, E. (1998).The Economic Costs of Illicit Drugs and Drug Enforcement. Policy Options, 19(October)

29. Visher, C., \& Travis, J. (2003). Transitions from Prison to Community: Understanding Individual Pathways. Annual Review Of Sociology, 29(1), 89-113.Retrieved from http://dx.doi.org/10.1146/annurev.soc.29.010202.095931.

30. Yussif, M. O. H. A. M. E. D., et al. "The risk of HBV and HIV transmission in long-haul truck drivers in Egypt." Int J Med Pharm Sci 6.2 (2016): 97-102. 
